\title{
Species Composition and Abundance in Uta Ewa Creek, Niger Delta Region, Nigeria
}

\author{
Akpan, I. I. \\ Department Of Science Laboratory Technology Akwa Ibom State College Of Arts And Science
}

\begin{abstract}
Study on the ichthyofauna of Uta Ewa Creek, Niger Delta Region, Nigeria was carried out for a period of 12 months. (January-December,2010). A total of 26 species of fish in 14 families were identified from the Creek to determine the species diversity and its abundance. The index of prepondence (IP) revealed that Chrysichthys auratus $(0.84 \%)$, Chrysichthys nigrodigitatus (1.25\%) and Liza grandisquamis $(0.42 \%)$ were the dominant species while Eleotris vittata (0.0003\%), Pellonula leonensis $(0.0007 \%)$ and Odaxothnissa mento $(0.0003 \%)$ were the least abundant species.
\end{abstract}

Keywords: Ichthyofauna, Creek, Uta Ewa, Niger Delta, Species

\section{Introduction}

Species and composition is an indicator of the habitat of a particular fish species in a certain aquatic environment. It could consist of the vertical composition or the horizontal composition (Martin \& Okadi, 2009). This enhances the knowledge on species' type and choice of fishing gear.

Fish and its products constitute the cheapest sources of animal protein, but according to Ndok (1982), they constitute of only $40 \%$ of the diet of an average Nigerian. Anko and Eyo (2003), noted that the Nigerian coastal zone has a great potentials for fisheries and development being endowed with a maritime area of $46,300 \mathrm{~km}^{2}$ an exclusive economic zone (EEZ) area of $210,900 \mathrm{~km}^{2}$ and inland waters of $12.5 \mathrm{~m}$ ha, however, inspite of the huge endowment, the current yield mark of 400,000 metric tons is at a 50\% deficit to meet the nation's fish need per annum of at least $1.5 \mathrm{~m}$ metric tons. Akpan (2006) noted that the bulk of the production comes from the local fishers, whose production level is still at deficit.

The challenge is geared towards increased domestic supply of fish by the proper development and management of the fishery resources of Niger Delta, Nigeria. However, many Nigerians showed a non challant attitude towards fisheries because of the low income of the fishers. This problem could be solved by the formation of cooperatives to encourage the fishers by the government. This will invariably improve on the income of the fishers, enhance fishing activities and also bridge the supply demand deficit gap.

Despite the importance of fishery, there is death of information on the artisanal fisheries of Uta Ewa creek, Niger Delta Region, Nigeria. This study will complement available information in the planning, formulation and execution of the fisheries development policies and strategies and serve as a baseline data for future development of the sector.

\section{Study Area}

\section{Materials and Methods}

This study was carried out at Uta Ewa Creek, around Ikot Abasi in Akwa Ibom State (Fig. 1). The sampling area lies between lat. $4^{\circ} 30^{\prime} \mathrm{N}$ and $4^{\circ} 45^{\prime} \mathrm{N}$ and longitude $7^{\circ} 30^{\prime} \mathrm{N}$ and $7^{\circ} 45^{\circ} \mathrm{e}$ (Enplan, 1974). The elevation of the area is generally less than $30 \mathrm{~m}$ above sea level. The basic geological formation is made up of loose materials formed on the alluvial coastal plain sand (Petter et. al., 1994).

Fish Sampling: Fish samples were collected form the commercial landings of artisanal and subsistence fishers that land their catches at the water from (Fig.1). The trip was conducted bi-weekly from January to December, 2010.

Length and Weight Measurement: During each trip measurements were taken from all the landed fishes in the selected canoes and speed boats using the procedure of Pauly (1983).

Data Analysis: The percentage composition of each species was calculated over the total for the station. Also, indices of species structure in the Creek were calculated as follows:

- $\mathrm{D}=\frac{\mathrm{ns}}{\mathrm{N}} \times 100$,

Where, $\mathrm{D}=$ relative abundance,

$\mathrm{ns}=$ no. of individual species. 
- $\quad \mathrm{IP}=\frac{\% \mathrm{~N} . \% \mathrm{~W}}{(\Sigma \% \mathrm{~N} . \% \mathrm{~W})} \times 100$,

Where, $\mathrm{N}=$ no. of fish species,

$\mathrm{W}=$ weight of fish

$\%=$ percentage

Fish with IP values of less than 0.10 were regarded as relatively insignificant, while IP values greater than 0.10 were regarded as being significant (Moses, 1987).

\section{Results and Discussion}

Ichthyofauna: A total of 668 specimens from 14 families consisting of 28 species were collected in the Uta Ewa Creek during the study period. The families embraced one or more species which differ in number from each other. The morphometric characteristic of the collected species revealed differences in length and body weight, which is natural (Table 1).

Investigations on the species composition of Uta Ewa Creek, Niger Delta Region, revealed a faunal assemblage comprising of 14 families and 28 species. The species distribution was found to be determined by the nature of the water system among other factors (Nwadiaro, 1989). The species and richness may be attributed to the fact that Uta Ewa Creek is linked to Atlantic Ocean through Imo River estuary, hence the presence of some intrusive species (Essien, 1990).

The fish species richness could also be due to increase in habitats available and probably the presence of variety of dietary items. This is in agreement with the report of Nwadiaro (1989), who noted that fish were distributed by order and increased with stream size and also the utilization of varied energy sources.

The Creek was found to be inhabited by three types of fish, brackish water, fresh water and marine species. It appears that some fresh water fishes moved into the Creek (Valiky, 1992). These include Chrysichthys auratus. These fishes exhibited tolerance of the brackish water and are probably euryhaline in nature.

The typically brackish water fishes at the Creek included Ethmalosa fimbriata and llisha africana, Welcomme (1986) noted that some of these species are probably stenohaline fishes and may have moved only within narrow limits of salinity changes. He also noted that species living the estuary comes from three sources which include: the freshwater stenohaline species which enter the zone during the flood, marine stenohaline species which enter inland at dry season and the euryhaline species of marine origin which live within the zone permanently. He listed the euryhaline fishes of marine origin to include the families clupeidae, mugilidae, lutjanidae, sciaenidae, arridae and carangidae. All these families were found in the Uta Ewa Creek.

The occurrence of both fresh water and marine fishes at the creek was probably due to wide variations in salinity. Some of the marine species could move long distances in the creek. This probably accounts for the presence of such marine fishes as Cynoglossus senegalensis and Pseudotolithus elongates, caranx hippos, a typical marine species could have move into the creek during flood tide. This is consistent with the report of Moses (1987), who noted that during flood, some fish species could move to another aquatic habitat with different characteristics. The flood water carries with it nutrients which enhance explosive growth of organism which form food for fish species (Nawa, 1985).

Moses (1987), also reported that estuaries are highly productive zones which benefit fisheries by providing nursery grounds and also open large feeding grounds to adult fishes at high tide. This assertion might account for the numerous species recorded proves that the Creek serves as a nursery ground. This is in agreement with Little et. al. (1987), who noted that Creek serves as a nursery ground, in which fingerlings are developed.

\section{Conclusion}

The commercial species of importance of Uta Ewa Creek, Niger Delta Region include Chrysichthys auratus, Chrysichthys nigrodigitatus, llisa africana, Ethamalosa fimbriata, Pseudotolithus elongatus, Pseudotolithus typhi and Liza grandisquamis. The fishery of the Creek can be used to be based on llisha africana with relative abundance of $16.48 \%$, Liza grandisquamis $(12.72 \%)$ and Lutjamis gorensis $(6.14 \%)$

\section{References}

[1]. Abowei, J. F. N., C. C. Tawari, A. I. Hart and D. U. Garicks (2008). Finfish species composition, abundance and distribution in the lower Somber River, Niger Delta, Nigeria. Int. J. Trop. Agric. Food System 2(1): 46-53.

[2]. Akpan, A. W. (1992). Limnological survey of Qua Iboe River in South Eastern Nigeria in relation to nutrient fluxes, physicochemical hydrology, organic carbon stocks and fluxes and faunal densities. Ph.D Thesis, University of Jos. Nigeria pp.361-363.

[3]. Akpan, I. I. (2006). Limnological study of Jaja Creek with special emphasis species composition, trophic biology and heavy metal composition of some selected species. M.Sc. Thesis, Dept. of Zoology University of Uyo, Uyo, pp.105-108

[4]. Allison, M. E. and Okadi, D. (2009). Species distribution and abundance in the lower Nun River, Niger Delta Nigeria. J. Fish. Inter (4) pp.13-18. 
[5]. Anko, E. O. and A. A. Eyo (2003). Fisheries development in Nigeria with special reference to Cross River State proceedings of the $16^{\text {th }}$ Annual Conference of fisheries society of Nigeria (FISON), Maiduguri $4^{\text {th }}-9^{\text {th }}$ November, 2001. In: Eyo, A. A. and E. A. Ajao (eds) Fison P. O. Box 2607, Apapa, Lagos pp.303-311.

[6]. Dan, I. S. (2004). Fish composition of an intertidal mangrove creek in Imo River Estuary, Department of Zoology B.Sc. Project University of Uyo, pp.35-40.

[7]. Edwards, A. J.; A. C. gill and P. O. Abohweyere (2001). A revision of Irvines marine fisheries of Tropical West Africa. Darwin Initiative Report 2, Ref. 162/7/1451,pp.156-158.

[8]. Enplan Consultant Engineers (1974). Imo River Basins Pre-feasibility Report. Vol.II Federal Ministry of Agriculture, Lagos pp.318.

[9]. Essen, A. A. (1982). Various types of Canoe fisheries in Ikot Abasi, proceedings to the $2^{\text {nd }}$ annual conference of fisheries society of Nigerian (FISON). Kainji Lake Research Institute, New Bussa pp.28-34.

[10]. Ita, E. O. (1993). Inland fishery resources of Nigeria CIFA Occa. Pap. No.20, Rome FAO pp.120-125.

[11]. Little, M. C., R. J. Ready and S. J. Grove (1988). The fish community of Eastern African Mangrove System Creek. J. Fish Biol 32; pp.729-749.

[12]. Moses, B. S. (1987). The influence of flood regime of fish catch communities of the Cross River floodplain ecosystem, Nigerian. Env. Bio. Fishes 18 (1) pp.51-56.

[13]. Nawa, I. G. (1985). A study on the growth of Pseudotolithus elongates, Chrysichthys nigrodigitatus and Cynogolossus goreensis occurring in the Cross River Estuary. In: Proceedings of the fisheries society of Nigeria (FISON) Port Harcourt. Fisheries society of Victoria Island, Lagos Nigeria pp.162-170.

[14]. Ndok, O. J. (19820. Proceedings of the $2^{\text {nd }}$ annual conference of the fisheries society of Nigeria (FISON) Kainji Lake Research Institute, New Bussa pp.295.

[15]. Nwadiaro, C. S. (1989). Ichthyofauna of Lake Oguta, a shallow lake of South Eastern Nigeria. Arch. Hydro. Biol. 115 (3) pp.463475 .

[16]. Olasebikan, B. D. and A. Raji (1998). Field guide to Nigerian freshwater fishes. Federal College of freshwater fisheries technology New Bussa, Nigeria, pp.47 ISBN: 34-760-0-0-9.

[17]. Pauly, D. (1983). Some simple methods of the assessment of tropical fish stocks FAO. Fish Tech. Pap. 234, pp.52-54.

[18]. Peters, S. W., E. R. Iwok and O. E. Uya (1994). Akwa Ibom: The Land of promise In: Peters, S. W; Iwok E. R. and Uya O. E. (eds) Gabumo Publishing Co. Ltd, pp.377.

[19]. Reed, W., J. Buchard, A. J. Hopson and I. Yaro (1967). Fish and fisheries of Northern Nigeria $1^{\text {st }}$ Edn. Min. Agric. N. Nig. pp.226.

[20]. Teugels, G. G., M. C. G. Reid and R. P. King (1992). Fishes of the Cross River Basin Nigeria. A review of exploited fish stocks. ECAF/ECAF. Series 86/40 FAO Rome, pp.60-62.

[21]. Udoidiong, O. M. (1988). A comparative study of the fish communities of two Nigerian headwater streams relation to manmade perturbation. Biological conservation 45:93-108.

[22]. Valiky, J. M. (1992). Assessing and managing the marine fish resources of Sierra Leone, West Africa NAGA 15 (1), pp.31-38.

[23]. Welcome, R. L. (1986). Fish of the Niger system In: Ecology of river system: Davies B. R. \& K. F. Walker (eds) Dr. W. Junks Publishers, Dordrecht. Netherlands pp.25-45.

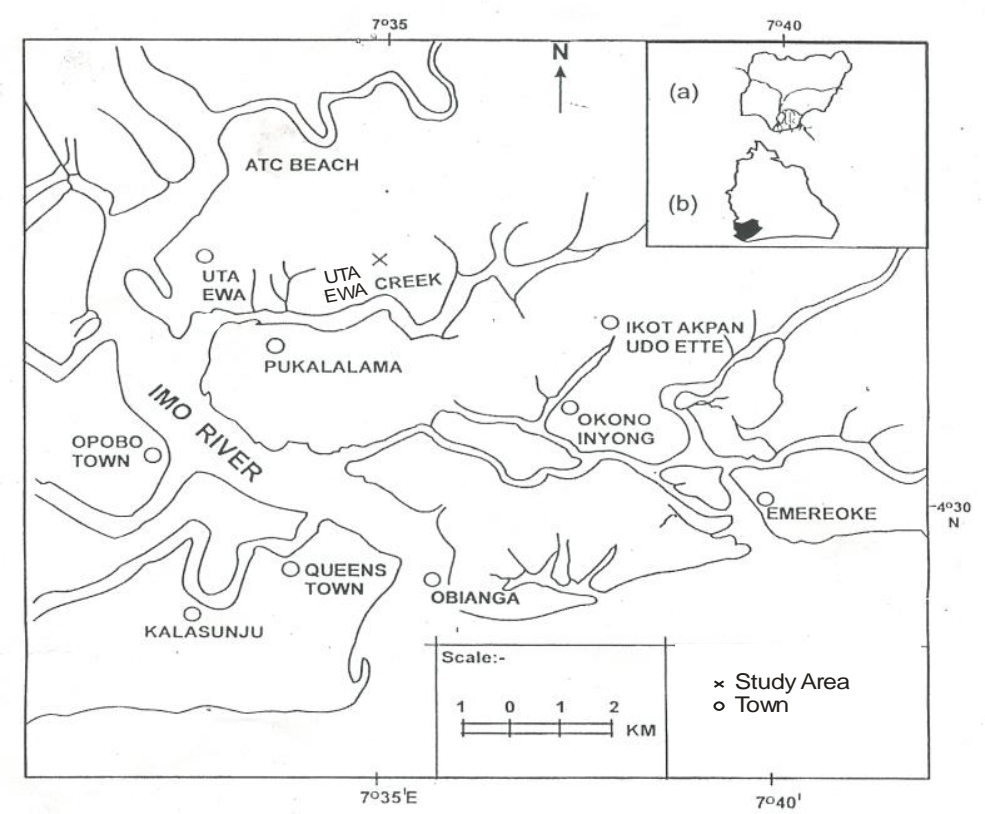

Fig.1: COASTAL ZONE OF SOUTH EASTERN NIGERIA, SHOWING UTA EWA CREEK Source: Enplan, (1974)

Insert (a): Map of Nigeria showing the location of Imo River estuary which Jaja Creek empties into

Insert (b): Map of Akwa Ibom State showing the location of Ikot Abasi 


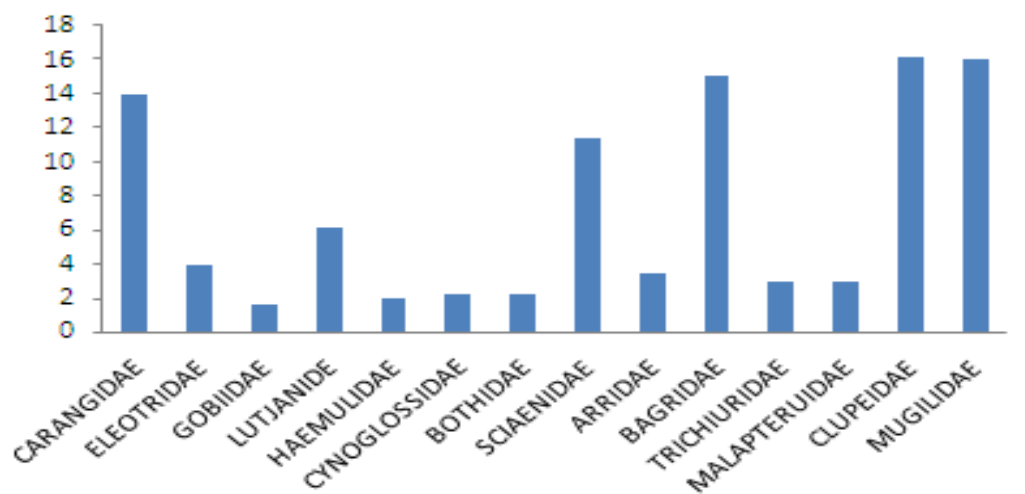

Fig. 2: Relative Abundance of Species in Uta Ewa based on Families

Table 1: Mean Length, Mean Weight and Relative Abundance of Fish Composition in Uta Ewa, Nigeria

\begin{tabular}{|c|c|c|c|c|c|}
\hline Family/Species & Total Catch & $\overline{\mathbf{x}} \mathbf{T L}(\mathbf{c m})$ & $\overline{\mathbf{x}} \mathbf{B W}(\mathbf{g})$ & RA (\%) & IP (\%) \\
\hline \multicolumn{6}{|l|}{ CARANGIDAE } \\
\hline Caranx hippos & 29 & .85 & 24.40 & 4.34 & 0.07 \\
\hline Trachinotus goreensis & 26 & 9.91 & 16.58 & 3.89 & 0.04 \\
\hline Trachinotus teraia & 38 & 8.04 & 6.65 & 5.69 & 0.02 \\
\hline \multicolumn{6}{|l|}{ ELEOTRIDAE } \\
\hline Eleotris senegalensis & 25 & 16.43 & 39.63 & 3.74 & 0.09 \\
\hline \multicolumn{6}{|l|}{ GOBIIDAE } \\
\hline $\begin{array}{l}\text { Bathygobius soporato } \\
\text { LUTJANIDAE }\end{array}$ & \multicolumn{3}{|c|}{ LUTJANIDAE } & 1.65 & 0.00003 \\
\hline Lutjanus gorensis & 41 & 9.35 & 18.43 & 6.14 & 0.07 \\
\hline \multicolumn{6}{|l|}{ HAEMULIDAE } \\
\hline $\begin{array}{l}\text { Posmadasys jubelini } \\
\text { CYNOGLOSSIDAE }\end{array}$ & \multicolumn{4}{|c|}{ CYNOGLOSSIDAE } & 0.04 \\
\hline $\begin{array}{l}\text { Cynoglossus senegalensis } \\
\text { BOTHIDAE }\end{array}$ & \multicolumn{4}{|c|}{ BOTHIDAE } & 0.15 \\
\hline Citharichthys stampfii & 15 & 12.90 & 8.05 & 2.25 & 0.01 \\
\hline \multicolumn{6}{|l|}{ SCIAENIDAE } \\
\hline Pseudotolithus & 17 & 12.80 & 34.68 & 2.55 & 0.06 \\
\hline Senegalensis & 35 & 21.89 & 91.60 & 5.24 & 0.31 \\
\hline Pseudotolithus elongates & 24 & 23.3 & 105.40 & 3.59 & 0.24 \\
\hline \multicolumn{6}{|l|}{ Pseudotolithus typhus } \\
\hline \multicolumn{6}{|l|}{ ARRIDAE } \\
\hline Arius gigas & 18 & 21.87 & 67.68 & 2.70 & 0.12 \\
\hline Arius heudoliti & 4 & 18.68 & 55.01 & 0.60 & 0.02 \\
\hline \multicolumn{6}{|l|}{ BAGRIDAE } \\
\hline Chrysichthys auratus & 35 & 23.10 & 251.50 & 5.24 & 0.84 \\
\hline Chrysichthys nigrodigitatus & 37 & 52.50 & 350.0 & 5.54 & 1.25 \\
\hline Bagrus docmack & 29 & 15.15 & 65.31 & 4.34 & 0.18 \\
\hline \multicolumn{6}{|l|}{ TRICHIURIDAE } \\
\hline \multicolumn{6}{|l|}{ MALAPTERUIDAE } \\
\hline Malapterus electricus & 20 & 13.70 & 53.20 & 2.99 & 0.10 \\
\hline \multicolumn{6}{|l|}{ CLUPEIDAE } \\
\hline Llisha africana & 70 & 25.85 & 30.12 & 10.48 & 0.20 \\
\hline Odoxothrissa mento & 3 & 1.80 & 14.00 & 0.45 & 0.0003 \\
\hline Ethmalosa fimbriata & 31 & 10.73 & 4.19 & 4.64 & 0.04 \\
\hline Pellonula leonensis & 4 & 5.25 & 1.90 & 0.60 & 0.0007 \\
\hline \multicolumn{6}{|l|}{ MUGILIDAE } \\
\hline Liza grandisquamis & 85 & 25.95 & 52.12 & 12.72 & 0.42 \\
\hline Mugil cephalus & 22 & 17.91 & 66.30 & 3.29 & 0.13 \\
\hline
\end{tabular}

$\begin{array}{lll}\overline{\mathrm{X} T L} & = & \text { Mean total length }(\mathrm{cm}) \\ \overline{\mathrm{X}} \mathrm{W} & = & \text { Mean Weight }(\mathrm{w}) \\ \mathrm{RA} & = & \text { Relative Abundance }(\%) \\ \mathrm{IP} & = & \text { Index of preponderance }(\%)\end{array}$

Table 2: $\quad$ Fish Species Composition in Some Coastal Waters of Nigeria 
Species Composition And Abundance In Uta Ewa Creek, Niger Delta Region, Nigeria

\begin{tabular}{lcl}
\hline Water System & Species Richness & Source \\
\hline Cross River & 166 & Teugel et. al. $(1992)$ \\
Imo River & 60 & Dan (2004) \\
Nun River & 25 & Allison and Okadi (2009) \\
Nung River & 19 & Udoidiong (1988) \\
Olamiri River & 26 & Orji and Akobuche (1989) \\
Kadua River & 28 & Ita (1993) \\
Sombriero River & 67 & Abowei et. al, 2008 \\
Qua Iboe River & 51 & Akpan (1992) \\
Udom Streem & 17 & Udoidiong (1988) \\
\hline
\end{tabular}

